\title{
Effects of Oxygen Flow Rates on the Physical Characteristics of Magnetron Sputtered Single-Phase Polycrystalline $\mathrm{Cu}_{2} \mathrm{O}$ Films
}

\author{
Feifan Yang ${ }^{a}$, Yibang Fan ${ }^{a}$, Jingjie Li ${ }^{a}$, Hongyuan Fu ${ }^{a}$, Guojiao Xiang ${ }^{a}$, Wenbo Peng ${ }^{a}$, Yijian Zhou ${ }^{a}$, \\ Yang Zhao $^{a^{*}}$ (D), Zhiqiang Zhen ${ }^{a}$, Gaoqiang Deng ${ }^{b}$, Hui Wang ${ }^{a}$ (D) \\ ${ }^{a}$ Henan University of Science and Technology, School of Physics and Engineering, Henan Key \\ Laboratory of Photoelectric Energy Storage Materials and Applications, Luoyang, 471003, China \\ ${ }^{b}$ Jilin University, School of Electronic Science and Engineering, State Key Laboratory on Integrated \\ Optoelectronics, Changchun, 130012, China
}

Received: June 24, 2020; Revised: September 19, 2020; Accepted: October 16, 2020

\begin{abstract}
The single-phase polycrystalline copper oxide $\left(\mathrm{Cu}_{2} \mathrm{O}\right)$ films were prepared on sapphire substrates by radio frequency (RF) magnetron sputtering technology which was characterized by low cost and high efficiency. The influences of oxygen flow rate on physical characteristics of the prepared films were investigated. The XRD results showed that the single-phase $\mathrm{Cu}_{2} \mathrm{O}$ film exhibited a (110) preferred orientation through the analysis of texture coefficient. The AFM images exhibited that the prepared $\mathrm{Cu}_{2} \mathrm{O}$ film had the highest surface roughness with a distinctive quadrangular surface morphology. The optical transmittance of the single-phase $\mathrm{Cu}_{2} \mathrm{O}$ film was under $35 \%$ and the band gap energy was calculated to be $2.30 \mathrm{eV}$, the absorption spectra included the peak wavelength of solar radiation and the high absorptivity made it to be a suitable absorbing material. The Hall measurement indicated that all the samples exhibited p-type conductivity. The resistivity, mobility and carrier concentration of the single-phase $\mathrm{Cu}_{2} \mathrm{O}$ film was $4625 \Omega \cdot \mathrm{cm}, 1.87 \mathrm{~cm}^{2} / \mathrm{v} \cdot \mathrm{s}$ and $7.227 \times 10^{14} \mathrm{~cm}^{-3}$, respectively.
\end{abstract}

Keywords: Magnetron sputtering; $\mathrm{Cu}_{2} \mathrm{O}$ films; Oxygen flow rate; P-type semiconductor.

\section{Introduction}

Cuprous oxide $\left(\mathrm{Cu}_{2} \mathrm{O}\right)$ is a kind of p-type semiconductor material with cubic structure and direct band gap ${ }^{1}$. Compared with the other inorganic p-type semiconductor materials ${ }^{2-6}$, it has been widely used in photo catalysis ${ }^{7}$ and humidity sensors ${ }^{8}$ due to its characteristics of rich sources, non-toxic, low preparation cost and high optical absorption coefficient ${ }^{9}$. Furthermore, it is also an attractive absorber layer for heterojunction solar cells because of a band gap energy of 2.1 2.6 $\mathrm{eV}^{10,11}$. Meanwhile, according to the calculation of the Shockley-queisser theory, the theoretical photoelectric conversion efficiency of the single-junction solar cell can reach $20 \%{ }^{12}$.

At present, the technologies for preparing semiconductor thin films include vacuum evaporation ${ }^{13}$, chemical vapor deposition $^{14}$, electrochemical sedimentation ${ }^{15}$, sol-gel ${ }^{16}$, electron beam evaporation ${ }^{17}$, solution growth ${ }^{18}$, molecular beam epitaxy ${ }^{19}$ and magnetron sputtering. Among them, RF magnetron sputtering has become one of the optimal methods to deposit $\mathrm{Cu}_{2} \mathrm{O}$ films due to its advantages of high deposition rate and strong controllability of the chemical composition and deposition of uniform films on large area substrates ${ }^{20,21}$. The various properties of $\mathrm{Cu}_{2} \mathrm{O}$ thin films prepared by magnetron sputtering were mainly depended on substrate temperature, oxygen partial pressure, sputtering power and substrate self-bias, etc. Among them, the oxygen partial pressure (oxygen flow rate) could affect the stoichiometric

*e-mail: 1wc9442@126.com ratio of copper and oxygen in the preparation of the film samples, which would be accompanied by the generation of $\mathrm{Cu}$ and $\mathrm{CuO}$. Eventually, the physical properties of film samples will be deteriorated ${ }^{22,23}$. In order to prepare singlephase $\mathrm{Cu}_{2} \mathrm{O}$ thin films, $\mathrm{Li}$ et al. ${ }^{24}$ have adopted $\mathrm{CuO}$ ceramics as the sputtering target by magnetron sputtering method under the mixed atmosphere of nitrogen and argon gas. It is found that the nitrogen doping can efficiently suppress the formation of $\mathrm{CuO}$ phase to obtain the single-phase $\mathrm{Cu}_{2} \mathrm{O}$ films. Zhu et al. ${ }^{25}$ fabricated $\mathrm{Cu}_{2} \mathrm{O}$ porous nanostructured films on glass slide substrates by magnetron sputtering system and the effects of electrons and argon ions on the deposition process were studied by quantitative calculation, a new model of tip charging effect was further proposed to account for the film forming mechanisms. In this work, we adopted a pure $\mathrm{Cu}$ as the target and the single-phase $\mathrm{Cu}_{2} \mathrm{O}$ films were obtained by adjusting the oxygen flow rate. In order to further explore the effect of deposition parameters on the single-phase $\mathrm{Cu}_{2} \mathrm{O}$ films, the surface morphology, crystal structure, optical and electrical characteristics of the thin films were investigated in detail.

\section{Experiments}

$\mathrm{Cu}_{2} \mathrm{O}$ films were deposited on $\mathrm{c}-\mathrm{Al}_{2} \mathrm{O}_{3}$ substrates by magnetron sputtering (JGP 300) equipment. Pure copper (99.999\%) of $50 \mathrm{~mm}$ diameter and $3 \mathrm{~mm}$ thick was used as the sputtering target. The pure sputtering gas (argon, $40 \mathrm{sccm}$, 99.99\%) and the reactive gas (oxygen, 99.99\%) were used 
in the experiments, the oxygen flow rates value from 1 to $5 \mathrm{sccm}$ were used to study the physical characteristics of the film samples. Before depositing, the substrates were placed in acetone, anhydrous ethanol and deionized water in sequence and respectively washed with ultrasonic for 5 minutes. Then the substrates were dried with high purity nitrogen and put into the vacuum chamber which was $350 \mathrm{~mm}$ high and $280 \mathrm{~mm}$ in diameter. Meanwhile, keeping the distance between the substrate plate and the sputtering target as $5 \mathrm{~cm}$. The deposition parameters were as follows. The base pressure of the chamber was below $1 \times 10^{-3}$ Pa using a turbomolecular pump and a roots pump. The chamber pressure was maintained at $1.0 \mathrm{~Pa}, \mathrm{RF}$ power was $120 \mathrm{~W}$, and the sputtering temperature was $400^{\circ} \mathrm{C}$ for $1 \mathrm{~h}$ for each group of experiments. The structure and orientation of the films were studied using X-ray diffraction (XRD, $\lambda_{\mathrm{Cu}, \mathrm{k} \alpha 1}=1.5406 \AA$ ). The diffraction angle for scanning was started from 23 to 65 degrees continuously with a scan rate of five degrees per minute. The atomic force microscopy (AFM) was used to analyze the morphological feature on a Veeco Dimension 3100 scanning probe microscope and the sampling range kept at $5 \times 5 \mathrm{um}^{2}$. The optical properties of the films were recorded using UV-2600 Spectrophotometer where the uncoated sapphire substrate was used as a reference. The electrical properties of samples were studied by ACCENT HL5500PC Hall system using the van der Pauw method. All characterizations were investigated at room temperature.

\section{Results and Discussion}

$\mathrm{X}$-ray diffraction results of the samples formed at different oxygen flow rates were shown in Figure 1. It could be noted that the sample deposited at low oxygen flow rate of $1 \mathrm{sccm}$ showed the obvious diffraction peaks at $2 \theta \sim 29.41^{\circ}$, $2 \theta \sim 36.54^{\circ}$ and $2 \theta \sim 61.08^{\circ}$ related to the (110), (111) and (220) planes for cubic $\mathrm{Cu}_{2} \mathrm{O}$ (JCPDS Card no.77-0199), respectively. Another peak observed at $2 \theta \sim 43.44^{\circ}$ corresponded to the (111) plane of cubic Cu (JCPDS Card no. 85-1326). In addition, there may be a diffraction peak of $\mathrm{Cu}_{2} \mathrm{O}(200)$ in the film located at $2 \theta \sim 42.36^{\circ}$. These results showed the sample presented a mixed phase of $\mathrm{Cu}_{2} \mathrm{O}$ and unreacted $\mathrm{Cu}$. Moreover, it is not difficult to find that the $\mathrm{Cu}_{2} \mathrm{O}(220)$ diffraction peak was shifted to a lower angle, and the lattice

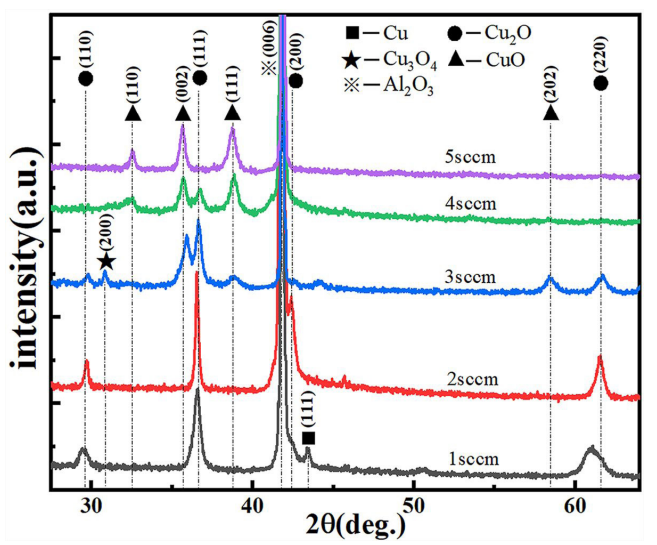

Figure 1. XRD pattern of the samples deposited on $\mathrm{Al}_{2} \mathrm{O}_{3}$ substrates at different oxygen flow rates. parameter evaluated from it was $0.429 \mathrm{~nm}$, which was bigger than the standard JCPDS data $0.425 \mathrm{~nm}$. This may be due to the stress induced by impinging high energy sputtered atoms or ions in the low gas flow rate ${ }^{26}$. When the oxygen flow rate was increased to $2 \mathrm{sccm}$, the diffraction peak of $\mathrm{Cu}$ (111) disappeared and the single-phase $\mathrm{Cu}_{2} \mathrm{O}$ was obtained. In addition, all the intensities of $\mathrm{Cu}_{2} \mathrm{O}$ diffraction peaks increased and the full width at half maxima (FWHM) decreased, especially for the $\mathrm{Cu}_{2} \mathrm{O}$ (200) diffraction. This may be due to the increasing of particle collision frequency with the increasing of oxygen flow rate, which had an impact on the growth of oriented $\mathrm{Cu}_{2} \mathrm{O}$ films ${ }^{27}$. Upon further increased the oxygen flow rate to $3 \mathrm{sccm}$, the XRD diffraction pattern changed obviously. The diffraction peak intensities of $\mathrm{Cu}_{2} \mathrm{O}$ decreased, and the $\mathrm{Cu}_{2} \mathrm{O}$ (200) diffraction peak was nearly disappeared. Meanwhile, four new peaks located at $2 \theta \sim 35.85^{\circ}$, $2 \theta \sim 38.83^{\circ}, 2 \theta \sim 58.34^{\circ}$ and $2 \theta \sim 30.76^{\circ}$ were appeared which were corresponding to (002), (111) and (202) planes of monoclinic structured CuO (JCPDS Card no.80-1917) and (200) plane of $\mathrm{Cu}_{4} \mathrm{O}_{3}$ subphase (JCPDS Card no. 03-0879), respectively. Further increased the oxygen flow rate to $4 \mathrm{sccm}$. The diffraction peak of $\mathrm{Cu}_{4} \mathrm{O}_{3}$ (200) disappeared and only $\mathrm{Cu}_{2} \mathrm{O}$ (111) diffraction with lower intensity was left. At the same time, the diffraction peak intensities of $\mathrm{CuO}(002)$ and (111) were further increased and a new peak of $\mathrm{CuO}$ (110) was generated instead of (202). Finally, single-phase $\mathrm{CuO}$ was obtained and both the intensities of $\mathrm{CuO}$ (110), (002) and (111) diffractions were increased because of more crystallites had been grown in the structure ${ }^{28}$ as the oxygen flow rate was increased to $5 \mathrm{sccm}$.

In order to further characterize the crystal structure of single-phase $\mathrm{Cu}_{2} \mathrm{O}$ film. Orientation of the crystallites in the $\mathrm{Cu}_{2} \mathrm{O}$ film synthesized at the oxygen flow rate of $2 \mathrm{sccm}$ is obtained by utilizing Harris texture analysis ${ }^{29}$. The value of the texture is quantified by the direct comparison of the integrated peak intensities of a textured film with those of an untextured powder sample. The texture coefficient (TC) of $\mathrm{Cu}_{2} \mathrm{O}$ sample is defined $\mathrm{as}^{30}$ :

$$
C_{(h k l)}=\frac{I_{i(h k l)} / I_{0 i(h k l)}}{(1 / N) \sum_{i=1}^{N} I_{i(h k l)} / I_{0 i(h k l)}}
$$

where $I_{0 i(h k l)}$ are the diffraction intensities of $\mathrm{Cu}_{2} \mathrm{O}$ powders from JCPDS Card no.77-0199. $I_{i(h k l)}$ are the measured relative intensities of $\mathrm{Cu}_{2} \mathrm{O}$ diffractions from the XRD pattern, and $N$ is the number of diffractions considered in the analysis. In addition, the standard deviation of all of the $\sigma$ value is also calculated according to the following equation:

$$
\sigma=\sqrt{\frac{\sum_{i=1}^{N}\left(C_{i(h k l)}-l\right)^{2}}{N}}
$$

Table 1 shows the values of $\mathrm{C}(\mathrm{hkl})$ for each plane and $\sigma$ for the single-phase $\mathrm{Cu}_{2} \mathrm{O}$ film deposited at the oxygen flow rate of $2 \mathrm{sccm}$. A C(hkl) value above 1 and a $\sigma$ value above 0 represent a preferential orientation of the (hkl) plane $^{31}$. According to Table 1, the sample shows a very strong (110) texture with the values $C_{(110)}=2.053$ and $\sigma=0.6197$. The calculation results display that the film has 
Table 1. The values of $C_{(h k l)}$ for each plane and $\sigma$ or the single-phase $\mathrm{Cu}_{2} \mathrm{O}$ sample.

\begin{tabular}{|c|c|c|c|c|c|}
\hline $\begin{array}{c}\text { Sample oxygen flow } \\
\text { rate }\end{array}$ & Reflected plane(hkl) & Intensity (Expt.) & $\begin{array}{l}\text { Intensity } \\
\text { (JCPDS) }\end{array}$ & $\begin{array}{c}\text { Texture } \\
\text { coefficient }\left(C_{(h k l)}\right)\end{array}$ & Standard deviation $(\sigma)$ \\
\hline \multirow{4}{*}{$2 \mathrm{sccm}$} & $(111)$ & 100 & 100 & 0.491 & \multirow{4}{*}{0.6197} \\
\hline & $(110)$ & 22.6 & 5.4 & 2.053 & \\
\hline & $(200)$ & 58 & 34.4 & 0.827 & \\
\hline & (220) & 33.8 & 26.4 & 0.628 & \\
\hline
\end{tabular}
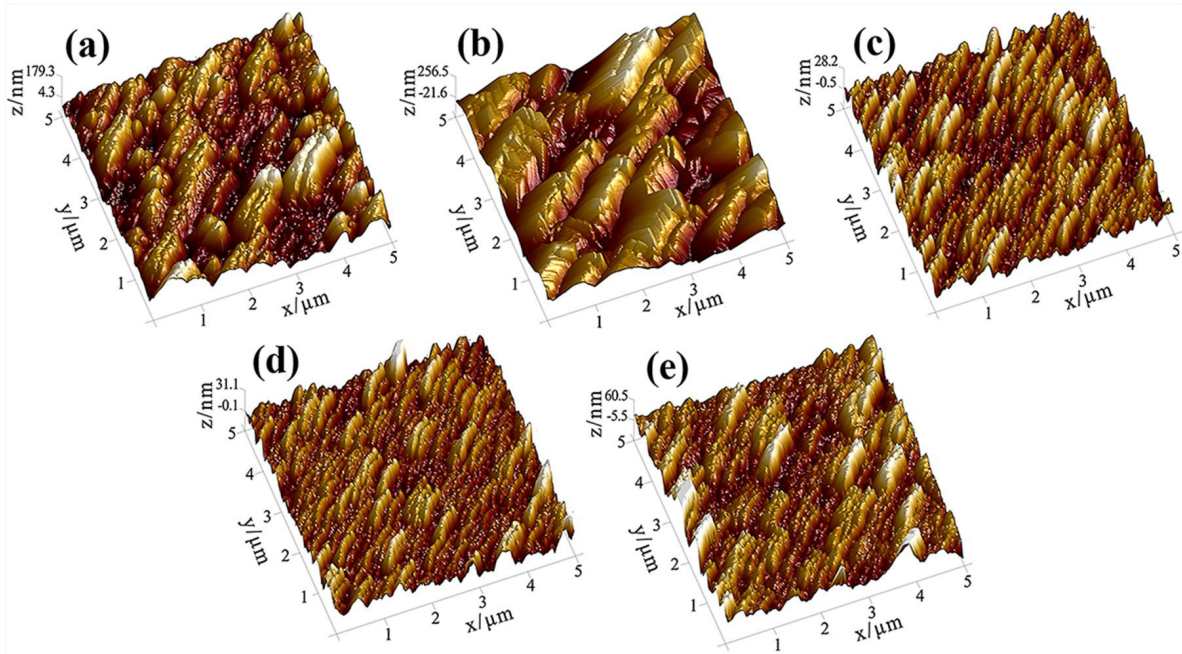

Figure 2. AFM images of samples deposited at various oxygen flow rates: (a) $1 \mathrm{sccm}$, (b) $2 \mathrm{sccm}$, (c) $3 \mathrm{sccm}$, (d) $4 \mathrm{sccm}$ and (e) $5 \mathrm{sccm}$.

a $\mathrm{Cu}_{2} \mathrm{O}$ (110) preferred orientation growth at the oxygen flow rate of $2 \mathrm{sccm}$.

Figure 2 showed the AFM image of samples deposited at various oxygen flow rates. The thin films showed the aggregating direction between the grains presented about 45 degrees with the $\mathrm{X}$-axis and Y-axis. When the oxygen flow rate was increased from 1 to $5 \mathrm{sccm}$, the corresponding root mean square surface roughness of the thin films were $42.2,58.2,20.5,6.89$ and 14.4, respectively. As could be seen from Figure $2 \mathrm{a}$, the surface of film showed a high surface roughness. Not only the grain size was inhomogeneity but there had some obvious gaps between the grains. Increasing the oxygen flow rate of $2 \mathrm{sccm}$, Figure $2 \mathrm{~b}$ showed the grain size of the single-phase $\mathrm{Cu}_{2} \mathrm{O}$ film had increased significantly due to the better crystallinity and the single component. The film had a distinctive quadrangular surface morphology with clear grain boundary, which was similar to the previous literature ${ }^{32}$. Figure $2 \mathrm{c}$ showed that the surface morphology of the film changed completely and the grain size decreased obviously, which caused the decrease of the film roughness. Increasing the oxygen flow rate to $4 \mathrm{sccm}$, the surface of the film was further refined with smaller grain size and minimum surface roughness. Then, the grains aggregated together as shown in Figure 2e as the oxygen flow rate was increased to $5 \mathrm{sccm}$. The increased grain size led to the film roughness increased again. This may be related to the formation of single-phase $\mathrm{CuO}$ with better crystalline quality of the film. Through the above analysis, it is found that the improvement of crystal quality and purity of the films will lead to the increase of grain size and the significant changes of surface texture.
According to the XRD results, the $\mathrm{Cu}$ ions could not fully react with oxygen when the oxygen flow rate was $1 \mathrm{sccm}$. This would lead to a low optical transmittance owing to the scattering of light by the metallic copper combined with $\mathrm{Cu}_{2} \mathrm{O}$. Therefore, this article do not take this sputtering condition into consideration in the representation of optical properties.

Figure 3 a showed the optical transmittance of the samples deposited at different oxygen flow rates. The transmittance spectra of the samples were recorded in the wavelength range of 440-1050 nm. It could be found that the transmittance spectra of sample A did not appeared an absorption edge because of the quantum size effects (QSE) ${ }^{27}$. Shogo et al. ${ }^{33}$ also explained that such an indistinct absorption edge may be due to the band tailing caused by a mixture of $\mathrm{Cu}_{2} \mathrm{O}$ crystalline phase and an amorphous phase. With the increasing of the oxygen flow rate, the absorption edge of the samples gradually exhibited red shift because of the proportion of $\mathrm{CuO}$ in the films was gradually increased. When the oxygen flow rate reached $5 \mathrm{sccm}$, the absorption edge of the film was approximately at $800 \mathrm{~nm}$, which was conformed to the optical transmittance spectra of $\mathrm{CuO}$. This result was consistent with the XRD conclusion. As a whole, the transmittance of both single-phase $\mathrm{Cu}_{2} \mathrm{O}^{34}$ and $\mathrm{CuO}$ films ${ }^{35}$ were lower than that reported in previous literatures. This was probably due to the vast crystal defects in the crystal, resulting in more light scattering and internal recombination caused by reflection ${ }^{36}$. It is this characteristic of high absorbance make the films to be a suitable semiconductor absorbing material ${ }^{23}$.

The direct optical band gap energy of the thin films can be estimated using linear extrapolation method by the following equation ${ }^{37}$ : 

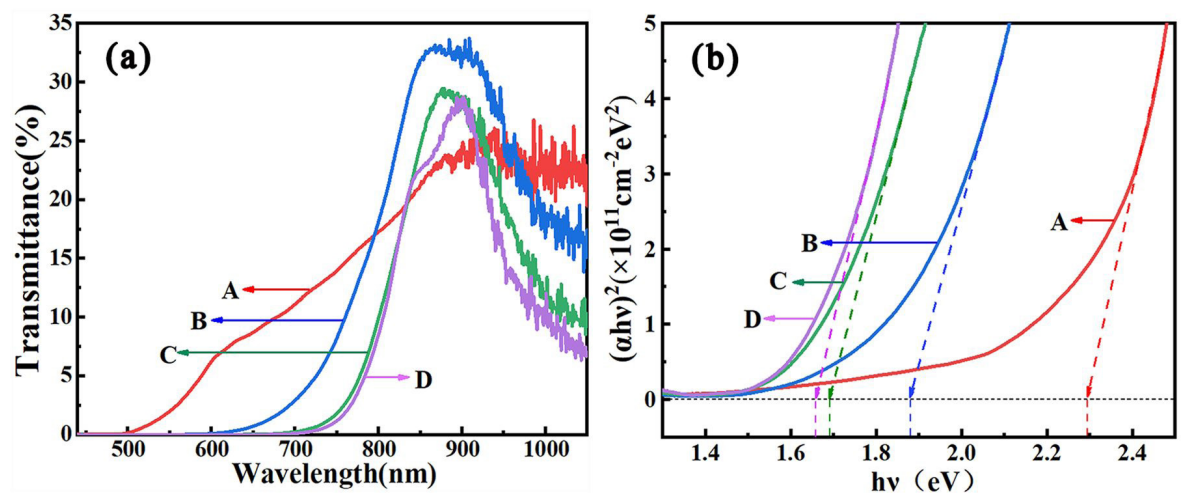

Figure 3. (a) Transmittance spectra of the samples A-D deposited at different oxygen flow rates. (b) Variation of $(\alpha \mathrm{h} v)^{2}$ versus photon energy ( $\mathrm{h} v$ ) of the samples A-D deposited at different oxygen flow rates: A $2 \mathrm{sccm}$, B $3 \mathrm{sccm}, \mathrm{C} 4 \mathrm{sccm}$ and D $5 \mathrm{sccm}$.

$\alpha h v=A\left(h v-E_{g}\right)^{\frac{1}{2}}$

where $\mathrm{A}$ is a constant, $\alpha$ is the absorption coefficient and hv is the photon energy. Figure $3 b$ showed the plots of $(\alpha h v)^{2}$ versus photon energy of the samples deposited at different oxygen flow rates. The $E_{g}$ corresponded to the sample A, B, C and D were about 2.30, 1.88, 1.69 and $1.66 \mathrm{eV}$ respectively, which presented a decreasing trend with the increasing of the oxygen flow rates. According to the curve of sample A, the $E_{g}$ of the single-phase $\mathrm{Cu}_{2} \mathrm{O}$ film was 2.30 $\mathrm{eV}$, which was in good agreement with the reported value of $\mathrm{RF}$ magnetron sputtered $\mathrm{Cu}_{2} \mathrm{O}$ films ${ }^{34}$. The decreasing value of $E_{g}$ was due to the generation of $\mathrm{CuO}$ phase, this phenomenon was similar with Alkoy and Prabu's research work $^{38,39}$. Further, as has been described earlier ${ }^{40}$, the observed change in $E_{g}$ is not only related to stoichiometry (x) of $\mathrm{Cu}_{\mathrm{x}} \mathrm{O}$ but nanocrystalline size in these films. From the AFM and $\mathrm{XRD}$ results, the particle size decreased due to the decline of crystal quality and the occurrence of non-stoichiometric ratio defects when the oxygen flow in excess of $2 \mathrm{sccm}$. The value of $E_{g}$ is expected to increase with the decrease in particle size given by effective mass approximation ${ }^{41}$. In this work, the crystallite size reduction due to defects causes a smaller affect in the $E_{g}$ than what is expected from the decrease in stoichiometry value $(\mathrm{X})$.

The electrical properties of samples deposited at different oxygen flow rates were studied at room temperature by Hall measurement using the van der Pauw method. The mobility and carrier concentration of the prepared samples were shown in Figure 4. It showed that the mobility and carrier concentration changed from 0.072 to $1.870 \mathrm{~cm}^{2} / \mathrm{v} \cdot \mathrm{s}$ and $7.227 \times 10^{14}$ to $2.360 \times 10^{17} \mathrm{~cm}^{-3}$, respectively. All of the films exhibited the p-type conductivity and the mobility of single-phase $\mathrm{Cu}_{2} \mathrm{O}$ film reached $1.870 \mathrm{~cm}^{2} / \mathrm{v} \cdot \mathrm{s}$, which was the maximum of all samples. The characteristic of high mobility makes $\mathrm{Cu}_{2} \mathrm{O}$ films are widely used in optoelectronic devices such as p-channel transistors to obtain a sufficiently large on-to-off current ratio ${ }^{42}$. The resistivity of the samples at the oxygen flow rates from 1 to $5 \mathrm{sccm}$ were $2557,4625,821.2$, 367.3 and $1813 \Omega \cdot \mathrm{cm}$, respectively. The increasing resistivity of the films was due to the decrease of the conductive metallic copper when the oxygen flow rate was increased from 1 to $2 \mathrm{sccm}^{23}$. The subsequent sharp decline of the resistivity was

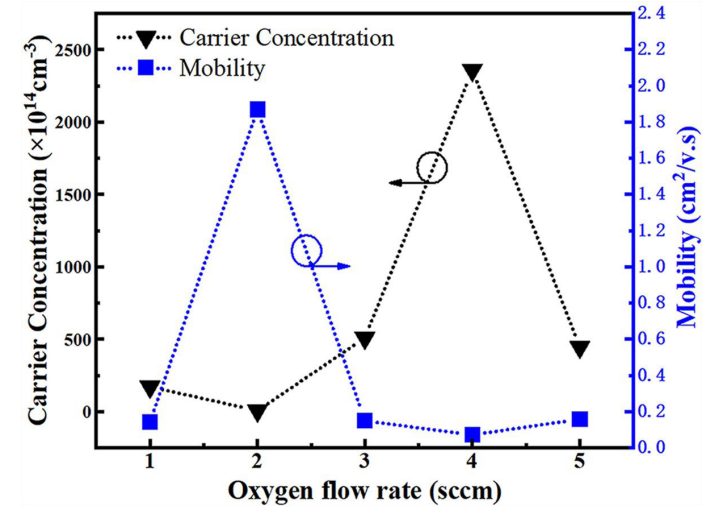

Figure 4. Hall mobility and carrier concentration of samples deposited at different oxygen flow rates.

due to the changing in crystallize quality and the formation of $\mathrm{CuO}$ phase, which causing the resistivity to be smaller than that of $\mathrm{Cu}_{2} \mathrm{O}$ based on the original electrical properties ${ }^{43}$.

\section{Conclusion}

In summary, the influences of oxygen flow rate on the physical properties of magnetron sputtered $\mathrm{Cu}_{2} \mathrm{O}$ films had been explored. Each of samples showed a polycrystalline structure. The single-phase $\mathrm{Cu}_{2} \mathrm{O}$ film with distinctive quadrangular surface morphology exhibited a strong $\mathrm{Cu}_{2} \mathrm{O}$ (110) preferred orientation through the analysis of texture coefficient. The absorption edge was gradually formed and exhibited red shift to the wavelength of $800 \mathrm{~nm}$ as the oxygen flow rate was increased. Moreover, the electrical characteristics of the samples showed that all of the films exhibited p-type conductivity and the optimum conductivity and mobility of the films could be obtained at appropriate oxygen flow rate. These results in this article provide a reference value for the preparation of high-performance $\mathrm{Cu}_{2} \mathrm{O}$ films by magnetron sputtering, and further promoting the extensive application of $\mathrm{Cu}_{2} \mathrm{O}$ materials in the field of optoelectronics.

\section{Acknowledgment}

This work was supported by the National Natural Science Foundation of China (Grant Nos. 61674052 and 11404097), 
the Key Scientific Research Projects of Higher Education Institutions of Henan Province, China (Grant No. 20A140012), the training plan of young backbone teachers in Colleges and universities of Henan Province (Grant No. 2018GGJS054), the Innovation and Entrepreneurship Training Program for Provincial Undergraduates of Henan Province (Grant No. S201910464024), the Student Research Training Program of Henan University of Science and Technology (Grant Nos. 2019208, 2020180 and 2020187), and the Student Research Training Program of School of Physics and Engineering of Henan University of Science and Technology (Grant No. WLSRTP201910).

\section{References}

1. Vitelaru C, Pana I, Kiss AE, Zoita NC, Vladescu A, Braic M. Tunability of $\mathrm{CuO}$ properties by gas flow rate control in the reactive DC magnetron sputtering. J Optoelectron Adv Mater. 2019;21:717-25.

2. Zhuang SW, Ma X, Hu DQ, Dong X, Zhang BL. Air-stable all inorganic green perovskite light emitting diodes based on $\mathrm{ZnO} / \mathrm{CsPbBr}_{3} / \mathrm{NiO}$ heterojunction structure. Ceram Int. 2018;44:4685-8.

3. Wang H, Zhao Y, Li XZ, Wu C, Dong X, Ma Y, et al. Nickel flux induced effects on structural and optical properties of $\mathrm{NiO}$ films fabricated by PA-MOCVD. Vacuum. 2015;119:77-80.

4. Zhao Y, Wang H, Gong XY, Li QZ, Wu GG, Li WC, et al. Near infrared electroluminescence from $\mathrm{p}-\mathrm{NiO} / \mathrm{n}-\mathrm{InN} / \mathrm{n}-\mathrm{GaN}$ lightemitting diode fabricated by PAMBE. J Lumin. 2017;186:243-6.

5. Shi ZF, Li Y, Zhang YT, Chen YS, Li XJ, Wu D, et al. Highefficiency and air-stable perovskite quantum dots light-emitting diodes with an all-inorganic heterostructure. Nano Lett. 2017;17:313-21.

6. Wang H, Zhao Y, Wu C, Wu GG, Ma Y, Dong X, et al. Ultraviolet electroluminescence properties from devices based on $\mathrm{n}-\mathrm{ZnO} / \mathrm{i}$ NiO/p-Si light-emittingdiode. Opt Commun. 2017;395:94-7.

7. Sahu K, Bisht A, Khan SA, Sulania I, Singhal R, Pandey A, et al. Thickness dependent optical, structural, morphological, photocatalytic and catalytic properties of radio frequency magnetron sputtered nanostructured $\mathrm{Cu}_{2} \mathrm{O}-\mathrm{CuO}$ thin films. Ceram Int. 2020;46:14902-12.

8. Muckley ES, Aytug T, Mayes RT, Lupini AR, Ivanov IN. Hierarchical $\mathrm{TiO}_{2}: \mathrm{Cu}_{2} \mathrm{O}$ Nanostructures for Gas/Vapor Sensing and $\mathrm{CO}_{2}$ Sequestration. ACS Appl Mater Interfaces. 2019;11:48466-75.

9. Mittiga A, Salza E, Sarto F, Tucci M, Vasanthi R. Heterojunction solar cell with $2 \%$ efficiency based on a $\mathrm{Cu}_{2} \mathrm{O}$ substrate. Appl Phys Lett. 2006;88:163502.

10. Zakutayev A., Stevanovic V, Lany S. on-equilibrium alloying controls optoelectronic properties in $\mathrm{Cu}_{2} \mathrm{O}$ thin films for photovoltaic absorber applications. Appl Phys Lett. 2015;106:123903.

11. Zhou L, Zhu YQ, Su JB, Liu Y, Lang XZ, Jiang MP, et al. Controllable fabrication of $\mathrm{Cu}_{2} \mathrm{O}$ porous nanostructured films by negative bias deposition method. Chin Sci Bull. 2017;62:3050-6.

12. Asim N, Sopian K, Ahmadi S, Saeedfar K, Alghoul MA, Saadatian O, et al. A review on the role of materials science in solar cells. Renew Sustain Energy Rev. 2012;16:5834-47.

13. Gevorkyan VA, Reymers AE, Nersesyan MN, Arzakantsyan MA. Characterization of $\mathrm{Cu}_{2} \mathrm{O}$ thin films prepared by evaporation of $\mathrm{CuO}$ powder. J Phys Conf Ser. 2012;350:012027.

14. Ikenoue $T$, Sakamoto $S$, Inui $Y$. Fabrication and characterization of $\mathrm{Cu}_{2} \mathrm{O}, \mathrm{ZnO}$ and ITO thin films toward oxide thin film solar cell by mist chemical vapor deposition method. Phys Status Solidi C. 2014;11:1237-1239.
15. Liang RM, Chang YM, Wu PW, Lin P. Effect of annealing on the electrodeposited $\mathrm{Cu}_{2} \mathrm{O}$ films for photoelectrochemical hydrogen generation. Thin Solid Films. 2010;518:7191-5.

16. Lim YF, Chua CS, Lee CJJ, Chi D. Sol-gel deposited $\mathrm{Cu}_{2} \mathrm{O}$ and $\mathrm{CuO}$ thin films for photocatalytic water splitting. Phys Chem Chem Phys. 2014;16:25928-34.

17. R. Oommen, U. Rajalakshmi and Sanjeeviraja. Characteristics of electron beam evaporated and electrodeposited $\mathrm{Cu}_{2} \mathrm{O}$ thin films - comparative study. Int J Electrochem Sci. 2012;7:8288-98.

18. Hu W, Cong H, Huang W, Huang Y, Chen LJ, Pan Al, et al. Germanium/perovskite heterostructure for high-performance and broadband photodetector from visible to infrared telecommunication band. Light Sci Appl. 2019;8:106.

19. Cong H, Yang F, Xue Cl, Yu K, Zhou L, Wang N, et al. Multilayer Graphene-GeSn Quantum Well Heterostructure SWIR Light Source. Small. 2018;14:1704414.

20. Dolai S, Das S, Hussain S, Bhar R, Pal AK. Cuprous oxide $\left(\mathrm{Cu}_{2} \mathrm{O}\right)$ thin films prepared by reactive d.c. sputtering technique. Vacuum. 2017;141:296-306.

21. Zhao Y, Wang H, Yang F, Zhen ZQ, Li XZ, Li QZ, et al. Influence of growth temperature on structure, optical and electrical properties of nickel oxide films by magnetron sputtering. Vacuum. 2018;151:163-6.

22. Li BB, Lin L, Shen HL, Boafo FE, Chen ZF, Liu B, et al. Effect of $\mathrm{N}$ doping on hole density of $\mathrm{Cu}_{2} \mathrm{O}: \mathrm{N}$ films prepared by the reactive magnetron sputtering method. Eur Phys J Appl Phys. 2012;58:20303

23. Hari Prasad Reddy M, Pierson JF, Uthanna S. Structural, surface morphological, and optical properties of nanocrystalline $\mathrm{Cu}_{2} \mathrm{O}$ and $\mathrm{CuO}$ films formed by $\mathrm{RF}$ magnetron sputtering: Oxygen partial pressure effect. Phys Status Solidi, A Appl Mater Sci. 2012;209:1279-86.

24. Li HJ, Pu CY, Ma CY, Li S, Dong WJ, Bao SY, et al. Growth behavior and optical properties of $\mathrm{N}$-doped $\mathrm{Cu}_{2} \mathrm{O}$ films. Thin Solid Films. 2011;520:212-6.

25. Zhu YQ, Ma J, Zhou L, Liu Y, Jiang MP, Zhu XF, et al. $\mathrm{Cu}_{2} \mathrm{O}$ porous nanostructured films fabricated by positive bias sputtering deposition. Nanotechnology. 2019;30:095702.

26. Balamurugan B, Mehta BR, Avasthi DK, Singh F, Arora AK, Rajalakshmi M, et al. Modifying the nanocrystalline characteristics - structure, size, and surface states of copper oxide thin films by high-energy heavy-ion irradiation. J Appl Phys. 2002;92:3304-10.

27. Zhu H, Zhang J, Li C, Pan F, Wang T, Huang B. $\mathrm{Cu}_{2} \mathrm{O}$ thin films deposited by reactive direct current magnetron sputtering. Thin Solid Films. 2009;517:5700-4.

28. Li JJ, Li XZ, Wang H, Zhao Y, Sun YY, Sun XJ, et al. Structural, Optical and Electrical Properties of Polycrystalline CuO Thin Films Prepared by Magnetron Sputtering. J Electron Mater. 2018;47:5788-92.

29. Kim KH, Chun JS. X-ray studies of $\mathrm{SnO}_{2}$ prepared by chemical vapor deposition. Thin Solid Films. 1986;141:287-95.

30. Consonni V, Feuillet G, Gergaud P. Plasticity induced texture development in thick polycrystalline CdTe: Experiments and modeling. J Appl Phys. 2008;103:063529.

31. Gao JN, Jie WQ, Yuan YY. Dependence of film texture on substrate and growth conditions for CdTe films deposited by close-spaced sublimation. J Vac Sci Technol A. 2011;29:051507.

32. Zhu H, Zhang J, Li C, Pan F, Wang T, Huang B. $\mathrm{Cu}_{2} \mathrm{O}$ thin films deposited by reactive direct current magnetron sputtering. Thin Solid Films. 2009;517:5700-4.

33. Ishizuka S, Maruyama T, Akimoto K. Thin-Film Deposition of $\mathrm{Cu}_{2} \mathrm{O}$ by Reactive Radio-Frequency Magnetron Sputtering. J Appl Phys. 2000;39:786-8.

34. Cai XM, Su XQ, Ye F, Wang H, Tian XQ, Zhang DP, et al. The n-type conduction of indium-doped $\mathrm{Cu}_{2} \mathrm{O}$ thin films fabricated by direct current magnetron co-sputtering. Appl Phys Lett. 2015;107:123903. 
35. Li JJ, Zhao Y, Wang H, Zhou YJ, Zhang M, Fu HY, et al. Effects of oxygen flow rates on the physical characteristics of magnetron sputtered CuO films. Vacuum. 2019;168:108811.

36. Yang M, Shi Z, Feng J, Pu H, Li G, Zhou J, et al. Copper doped nickel oxide transparent p-type conductive thin films deposited by pulsed plasma deposition. Thin Solid Films. 2011;519:3021-5.

37. Tauc J, Grigorovici R, Vancu A. Optical Properties and Electronic Structure of Amorphous Germanium. Phys Status Solidi, A Appl Res. 1966;15:627-37.

38. Alkoy EM, Kelly PJ. The structure and properties of copper oxide and copper aluminium oxide coatings prepared by pulsed magnetron sputtering of powder targets. Vacuum. 2005;79:221-30.

39. David Prabu R, Valanarasu S, Ganesh V, Mohd Shkir S, AlFaify, Kathalingam A, Srikumar SR, Chandramohan R. An effect of temperature on structural, optical, photoluminescence and electrical properties of copper oxide thin films deposited by nebulizer spray pyrolysis technique. Mater Sci Semicond Process. 2018;74:129-35.

40. Balamurugan B, Mehta BR. Optical and structural properties of nanocrystalline copper oxide thin films prepared by activated reactive evaporation. Thin Solid Films. 2001;396:90-6.

41. Kormann C, Bahnemann DW, Hoffmann MR. Preparation and characterization of quantum-size titanium dioxide. J Phys Chem. 1988;92:5196-201.

42. Matsuzaki K, Nomura K, Yanagi H, Kamiya T, Hirano M, Hosono $\mathrm{H}$. Epitaxial growth of high mobility $\mathrm{Cu}_{2} \mathrm{O}$ thin films and application to p-channel thin film transistor. Appl Phys Lett. 2008;93:1269.

43. Figueiredo V, Elangovan E, Gonçalves G, Barquinha P, Pereira L, Franco N, et al. Effect of Post Annealing on the Properties of Copper Oxide Thin Films Obtained from the Oxidation of Evaporated Metallic Copper. Appl Surf Sci. 2008;254:3949-54. 